\title{
A PALEODEMOGRAPHIC / MORTUARY STUDY OF GRAVES FROM THE EASTERN NECROPOLI AT ROMAN VIMINACIUM
}

\begin{abstract}
This article presents an overview of paleodemographic data obtained from six field seasons of osteological research at Viminacium - provincial city on the Danubian frontier of the Roman Empire. Skeletal remains from 254 graves - representing 297 individuals - excavated from four cemeteries situated about the eastern perimeter of the ancient city were analyzed for the study. Results suggest that the skeletal sample examined may be considered generally representative of the ancient mortality profile from the population as a whole. Key demographic details emerging from the research include a persistent preponderance of males within the population of Viminacium throughout its existence, albeit accompanied by evidence for considerably greater survivorship among females at most ages. Some interesting mortuary findings also emerge from the study, such as a trend in declining use of wooden coffins in the last century of occupation and disproportionate investment in burial treatment for certain females.
\end{abstract}

KEYWORDS: ROMAN PALEODEMOGRAPHY, MORTUARY ANALYSIS, PROVINCIAL ROMAN SOCIAL STRATIFICATION, EXCESS MALE MORTALITY IN ANTIQUITY, ROMAN FRONTIER URBANISM

The ancient settlement of Viminacium had its origins as a military outpost on the Danube frontier of the Roman Empire in the 1st Century AD (Fig. 1). Fortifications at Viminacium were established at sometime around 60 or $70 \mathrm{CE}$ with the arrival of the legion VII Claudia from the Dalmatian coast far to the southwest (Radojčić and Vasić 2003:114). As was common on the frontiers of the empire (Woolf 1998, Wells 1999), a civilian community soon sprang up in association with the military installation that consisted of merchants and local traders servicing the outpost. In the case of Viminacium, this settlement eventually coalesced into a heterogeneous urban center that expanded to some 220 densely settled hectares with a dispersed peripheral occupation sprawling to perhaps twice that. It is said to have been one of the largest cities on the lower Danube during Late Antiquity, with an estimated population of some 30,000 persons based upon acreage and capacity of the aqueducts supplying water to the town (Mócsy 1974; Spasić-Durić 2002). Viminacium had a long political ascendancy as part of the Emipre (Mirković 1968). Having become the effective capital of the province of Moesia at the beginning of the 2nd Century AD, it was awarded the formal title of municipium during the reign of Hadrian (AD 117-138), and eventually earned even greater status as colonia in the time of Gordian III (AD 238-244). In achieving this, Viminacium had reached the highest formal political rank afforded to a provincial city of the Roman Empire and served as the capital of the province of Upper Moesia well into the 4th century as the Empire 


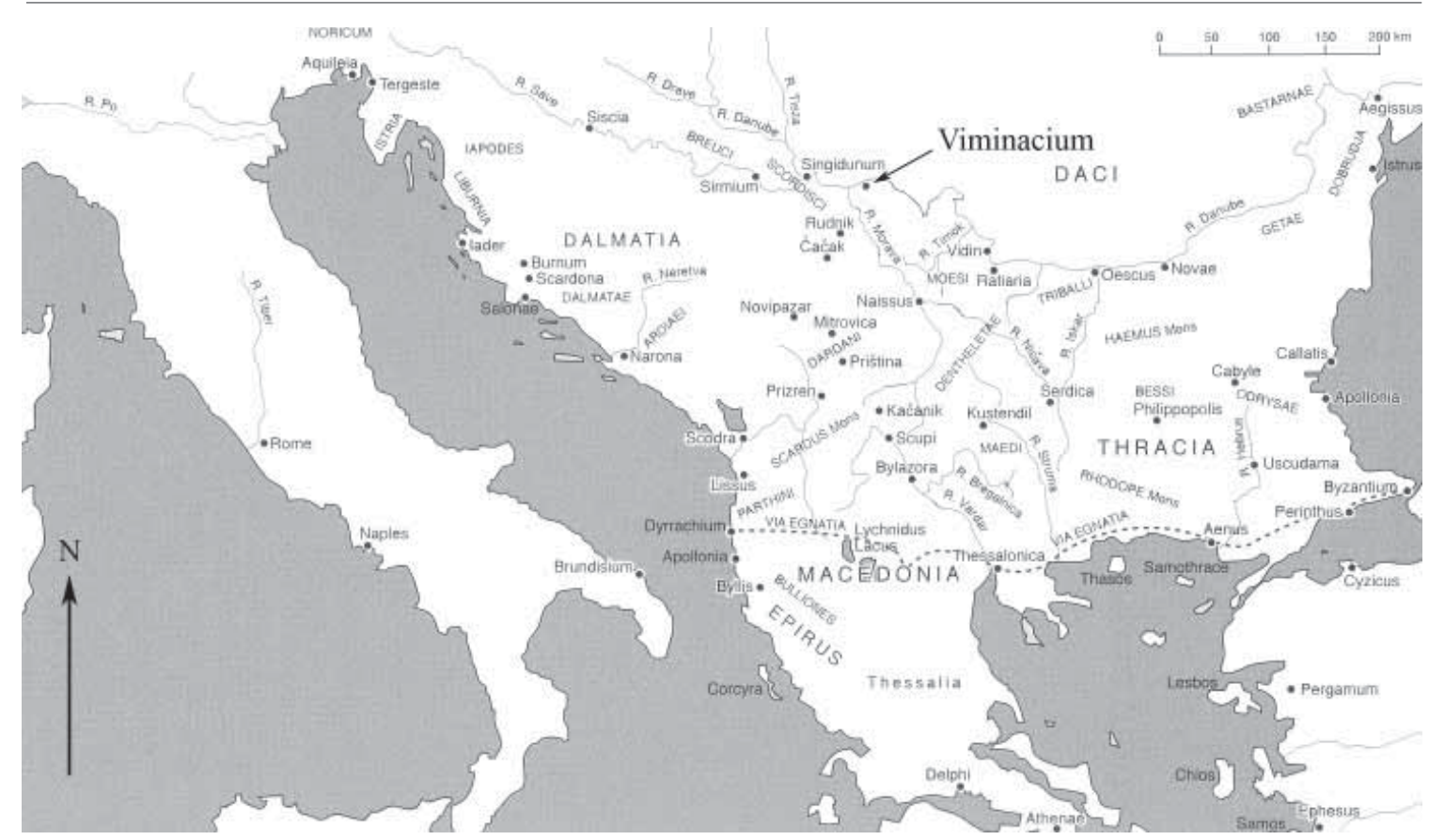

Fig. 1 Location of Viminacium within the Roman Balkans (modified from Syme 1999).

was restructured. The settlement appears to have been abandoned fairly rapidly after depredations by the Huns at around AD 441.

As was the case at virtually all Roman settlements, tradition - and probably law as wellmandated that all remains of the deceased at Viminacium were to be disposed of extra mur$o s$, or outside the city walls. The city therefore eventually became encircled by tens of thousands of graves organized into more than half a dozen cemeteries (Zotović and Jordović 1990). At least 13,000 individuals have been exhumed from these areas since 1972 as a result of construction and operation of a large thermo-electrical plant and its accompanying coal strip-mine between the towns of Kostolac and Drmno in eastern Serbia. Virtually all the burials encountered at Viminacium, with the exception of some from the very late 4th Century or possibly other periods of major external threat, were recovered from outside the settlement's ancient fortifications. Previous osteological and mortuary work at the site has resulted in description of many of these graves and their contents, which date to between the 1st and 5th Century AD (Zotović and Jordović 1990; Korać and Golubović 2009), and presented analyses of some select aspects of the skeletal remains, such as medical and culturally aesthetic modifications to the skull (Jovanovic 1984; Mikic 1994, 1996, 2006). Most of the site remains as a protected archaeological park today (Fig. 2).

\section{SAMPLE DESCRIPTION}

The collection of skeletal remains examined for this study consisted of 297 individuals from 254 graves more recently excavated from four more or less distinct cemeteries situated about the perimeter of the ancient city. This sample must be considered, for the most part, opportunistic. While every attempt was made to make use of graves from the most spatially disparate locations representing all time periods and burial form, this effort was necessarily restricted by access to only those remains recovered from salvage excavations undertaken between 2001 and 2008. Only those available remains sufficiently preserved to yield age at death data beyond an adult/subadult distinction were analyzed. Many excavated 


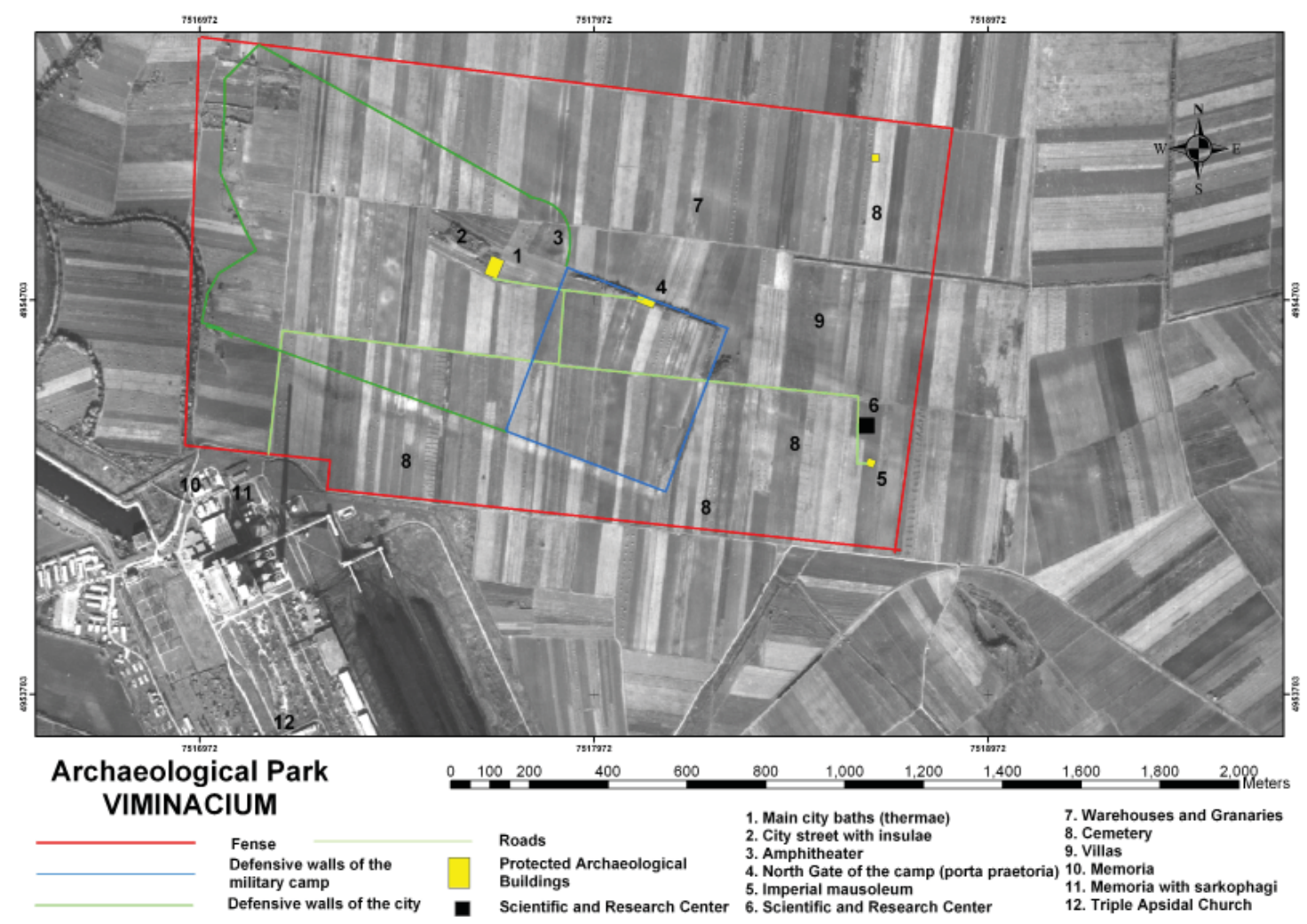

Fig. 2 Satellite view of modern Viminacium Archaeological Park and key associated features (Courtesy of Miško

Korać at the Archaeological Institute of Belgrade). Danube River is located to the north and northwest of photo.

graves were therefore rejected for this study as a result - including virtually all cremations, which are very common at the site - composing perhaps 40 to $50 \%$ of the total burials from the graveyards involved. For this reason, it was necessary from the outset to test the hypothesis that the available skeletal assemblage could be considered representative of the ancient mortality profile. Much of the remainder of this paper will be devoted to evaluating that supposition. In the end it was determined that, despite the limitations of the sample, its demographic composition and similarity to that described from other previously excavated cemeteries at Viminacium support the hypothesis that the collection analyzed reflects a reasonably representative subset of the mortality assemblage from the ancient city as a whole.

Cemeteries contributing to the skeletal sample examined include Kod Koraba ( $\mathrm{n}=60$ ), lying to the southwest of the city at some distance, Pirivoj $(n=226)$, a broad expanse of graves beginning just outside the eastern gate of the legionary fort or castrum, Rit $(\mathrm{n}=5)$, situated down on the Danube River floodplain to the northeast, and Pećine $(n=6)$, lying to the southeast of the city itself (Fig. 3). Forms of interment observed in the present sample range from individuals buried in crypts or sarcophagi $(n=46)$, to those placed in simple brick or tile lined graves $(n=41)$, to those placed in wooden coffins as evidenced by a series of nails around the perimeter of the grave $(n=73)$, to those interred with no encasement whatsoever $(n=127)$. While specific temporal information is lacking for many if not most of the graves - pending completion of ceramic analyses - indications are that the sample consists of more or less proportional representation from most periods of the full breadth of the city's occupation. They consist of relatively equal numbers of late 1 st Century to 2nd Century $(n=28), 3$ rd Century $(n=24)$, and 4th Century 


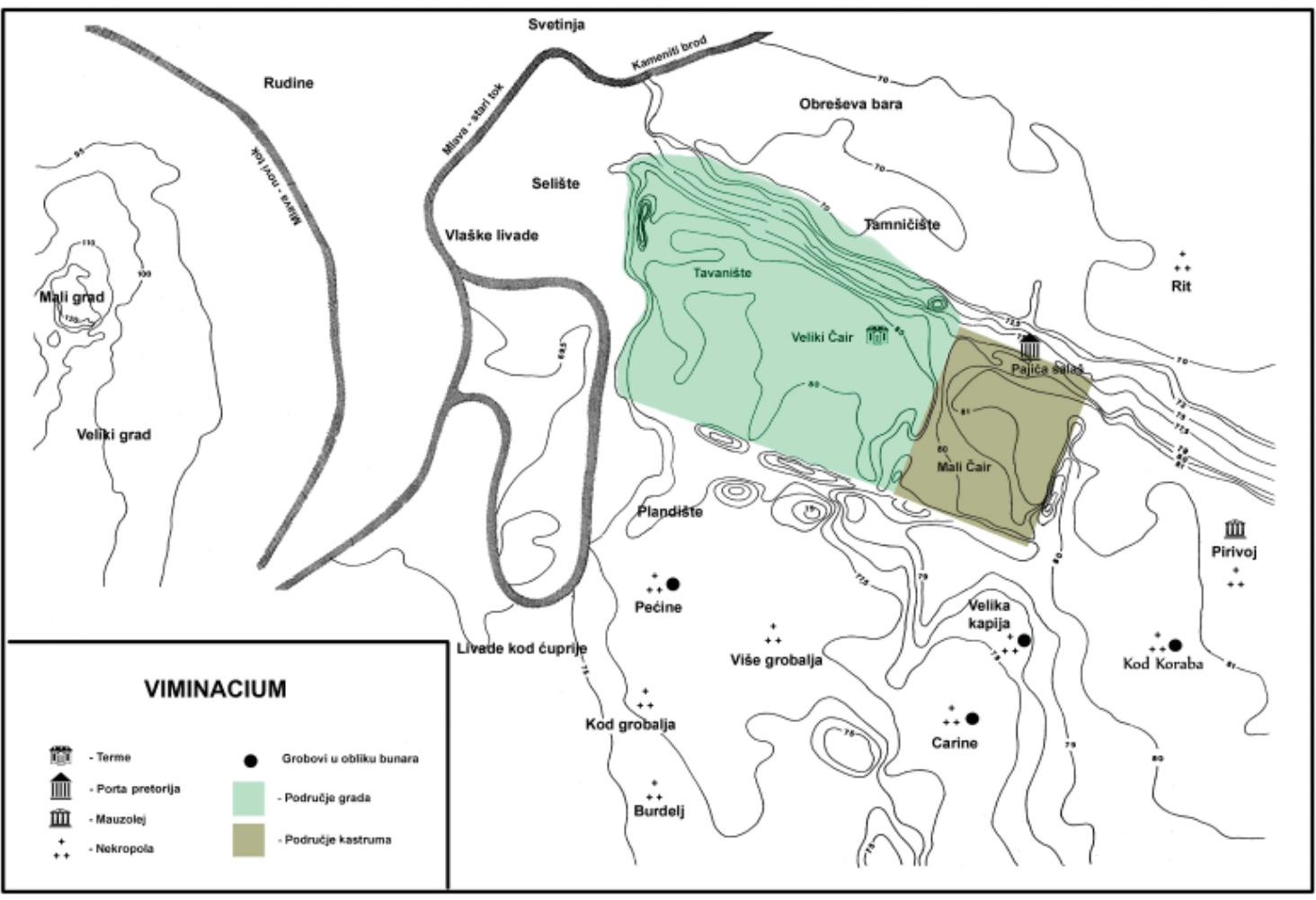

Fig. 3 Location of known cemeteries relative to ancient site of Viminacium (Courtesy of Miško Korać at the Archaeological Institute of Belgrade).

$(\mathrm{n}=43)$ burials. Missing from the skeletal sample are remains from the earliest and latest periods of occupation at Viminacium. This is probably more of an advantage than liability to the study though, as processes surrounding the formation and demise of a settlement are expected to be highly erratic and unstable, and therefore do not well represent the demographic forces acting within the population over the greater part of its existence.

\section{ATTRIBUTION OF SEX}

The biological sex of each individual was estimated through examination of both cranial and pelvic morphology, as available. Different weights were assigned to individual attributes based upon their established reliability. Pelvic indicators were considered most reliable, and those characteristics most heavily weighted include presence of a ventral arc, subpubic concavity, and thickness of the medial aspect of the ischiopubic ramus (Phenice 1969), presence of auricular elevation, shapes of the pelvic inlet, sacrum, ilium and pubis (Bass 2005), the presence and morphology of a preauricular sulcus, and the contour of the greater sciatic notch (Buikstra and Ubelaker 1994). Also taken into account were the contour of the iliac crest, the arcuate line, and the iliac fossa (Workshop of European Archaeologists 1980). Cranial morphology was considered in the assessment of sex, but was given less weight in the final attribution. Characteristics examined include size and mass of the mastoid processes, prominence of glabella and the mental eminence, nuchal relief, and sharpness of the supraorbital margins (Buikstra and Ubelaker 1994) slope of the forehead, frontal bossing, and the gonial angle and gonial flare of the mandible (Krogman 1962), and the overall shape of the chin in superior view (Bass 2005). While data regarded by certain researchers as indicative of sex in subadults was collected (Schutkowski 1993), it 


\begin{tabular}{|c|c|c|c|c|}
\hline Time Period & $1^{\text {st }}-2^{\text {nd }}$ Cent & $3^{\text {rd }}$ Century & $4^{\text {th }}$ Century & Total \\
\hline Male & 11 & 11 & 14 & 36 \\
\hline Female & 4 & 5 & 10 & 19 \\
\hline Sex Ratio & 2.75 & 2.2 & 1.4 & \\
\hline
\end{tabular}

Table 1: Sex Ratio by Time Period at Viminacium

was not deemed internally consistent or reliable enough for inclusion here and the sex of pre-adolescent individuals is considered indeterminate for purposes of this study.

Analysis resulted in determined sex for 166 individuals - 52 clearly female, 12 probable females, 14 probable males, and 88 clearly male. Combining 'probables' with 'definites' yields an overall sex ratio of 1.59 , which suggests that the aggregate population of Viminacium consisted of about 1.6 males to every female. This predominance of males was not unexpected given that the settlement was originally founded as a military outpost, and that this function remained as a core socio-economic influence on the community throughout its existence. One could make the argument that the present sample may be biased toward this military element of the past population given the physical proximity of the cemeteries best represented to the legionary castrum immediately to the east of the city itself. Yet the descriptive results of other skeletal series from Viminacium, such as that recovered from excavations directly south of the city walls at a cemetery known as Više Grobalja (Zotović and Jordović 1990:114), present a nearly identical sex ratio of 1.54 ( $\mathrm{n}=241$ determined individuals). This tends to confirm the representativeness of the present sample towards the ancient population as a whole, at least with regard to sex, and suggests that the cemeteries surrounding Viminacium may have been quite heterogeneous in socio-economic composition and not strongly segregated with regard to service in or relationship to the military legions.

It is also possible to examine changes in population structure through time with regard to sex. Though much temporal information was not avail- able to the author at the time of analysis - making sample sizes of determined sex for each individual time period unduly small $(\mathrm{n}=55)$ - preliminary analysis suggests an extraordinarily high sex ratio in the earliest periods followed by a decreasing disparity through time (Table 1). This is as would be expected given that civilian elements of the city would only slowly grow to rival the military aspect of the founding population in size. Even in the 4th Century, however, the population of Viminacium appears to have been predominantly male. This finding tends to confirm the propositions of some scholars that pre-Industrial cities were generally perceived as dangerous, dirty, unhealthy, and undesirable places that tended to be predominantly the domain of males (Wrigley 1967; Fenner 1970; Cohen 1989; Storey 2006). Again, the sample sizes are too small to conclusively test this as a hypothesis, but initial results tend to support the idea. Viminacium appears to have been a predominantly male settlement throughout its existence, albeit decreasingly so through time.

\section{AGE AT DEATH ASSESSMENT}

Age-at-death information was obtained from the skeletons using both traditional means of age assessment and several newly developed techniques that facilitate demographic analysis. In order to maintain comparability with other skeletal series, standard aging techniques well-established in the literature were employed as a baseline. These traditional methods included dental eruption and formation (Ubelaker 1989; Hillson 2005), epiphyseal union (Buikstra and Ubelaker 1994), and long bone length regression (Bass 
Age at Death Distribution by Phase

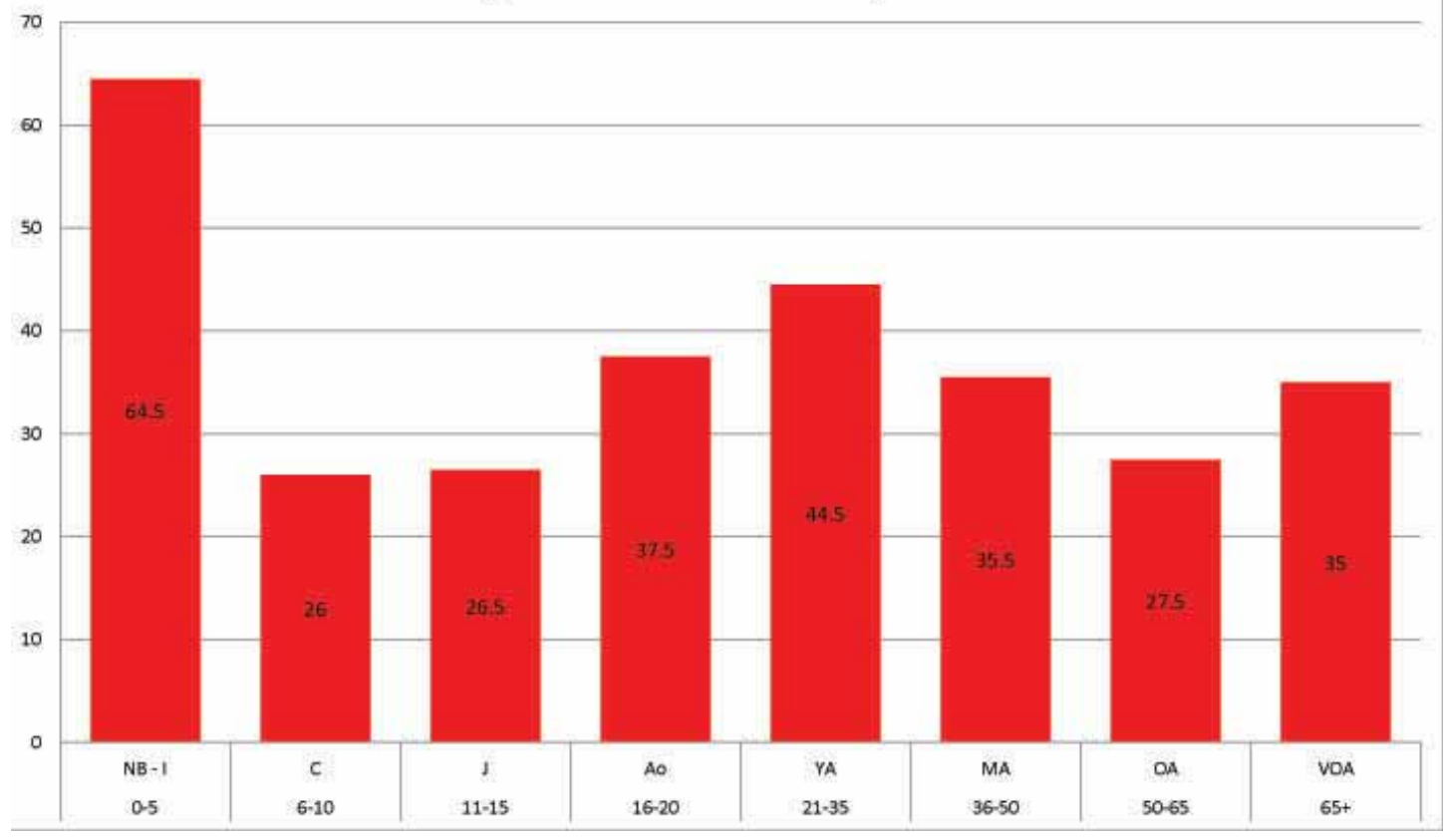

Fig. 4 Raw Counts (y-axis) of Skeletal Individuals by Age Phase in Present Study. Non-whole numbers represent individuals grouped across phases and allocated proportionally. (Age phase: $\mathrm{NB}=$ newborn, $\mathrm{I}=\mathrm{Infant}, \mathrm{C}=\mathrm{child}, \mathrm{j}=$ juvenile, $\mathrm{Ao}=$ adolescent, $\mathrm{YA}=$ young adult, $\mathrm{MA}=$ middle adult, $\mathrm{OA}=$ old adult, $\mathrm{VOA}=$ very old adult $)$.

2005) for sub-adults. For adults, they consisted of assessment of developmental changes in the pubic symphysis (Todd 1920; Brooks and Suchey 1990), the auricular surfaces (Lovejoy et al. 1985; Buckberry and Chamberlain 2002), and the sternal ends of the ribs (Iscan et al. 1984, 1985; Iscan and Loth 1986). Each skeleton was placed into an age category based upon the results in order to obtain a general idea of the individual's age at death, as well as to compile a raw assessment of the overall age at death distribution of the skeletal sample. The results of the overall age at death distribution assessment based upon traditional methods of estimation are presented as Fig. 4.

While crude constructs such as raw age at death distributions by lumped osteological age phase tell us relatively little about ancient demographic processes, they do allow for some potentially useful comparative assessments with other relevant archaeological skeletal assemblages. For instance, the ratio of children $(<21)$ to adult $(>20)$ skeletons in the present assemblage can be calculated at 0.65 . This is not substantially differ- ent from the same ratio $(0.59, \mathrm{n}=383)$ obtainable from descriptive information published from the cemetery at Više Grobalja (Zotović and Jordović 1990:114), located to the south of the city walls. Though these statistics are lacking in sophistication, the results again suggest that the cemeteries located to the east of the castrum do not differ meaningfully in demographic composition from those elsewhere around the city. If anything, there were proportionally more children recovered from the eastern graveyards closer to the legionary fort examined by the present study.

A major methodological advantage of the current study was its use of more sophisticated and precise techniques of estimating age-at-death from human remains. Paleodemography has suffered a long series of critiques that bemoan the vulnerabilities of the discipline to various biases, statistical difficulties, and problematic unknowns (Bocquet-Appel and Masset 1982; Sattenspiel and Harpending 1983; Bocquet-Appel 1985; Buikstra et al. 1985). The recently developed Boldsen-Milner "transition analysis" approach to skeletal ag- 
ing, in an attempt to resolve some of these issues, modifies previous techniques of scoring the pubic symphysis, auricular surface, and cranial suture closure by examining individual changes within each morphological system and providing an integrated result (Boldsen 1997, et al. 2002). Rather than lumping these results into age phases on the basis of overall morphology, the computational method yields a point estimate for the age-at-death of each individual based upon Bayesian maximum likelihood techniques, as well as a statistically determined confidence interval for the range of error. Approaches to aging using the sternal rib ends can also be modified to yield an age point estimate using multiple scores obtained from the same individual (Yoder et al. 2001; Speal 2008). These new techniques have the decided advantage of resulting in a statistically determined point estimate for the age-at-death for each individual. While the likelihood of each point estimate actually representing the age-at-death for any given individual is extremely small, if the error produced by the estimates can be assumed to be random and more or less normally distributed then this measure of central tendency can be used in more powerful techniques of demographic analysis when a large number of individual cases are available.

\section{MORTALITY PROFILE}

The age-at-death data obtained through the above described techniques were analyzed and processed using an event history approach to survival analysis with the help of applications of the statistical computer program STATA, developed by researchers at Texas A\&M University (Cleves et al. 2008). Age-at-death point estimates derived from transition analysis maximum likelihood calculations, sternal rib end phase composites, and subadult period midpoints were used to calculate single year hazards of mortality for the skeletal sample. In the case of adults with both sternal rib data and transition analysis markers in the cranial and pelvic region, the point estimates were combined using a mean weighted by the number of markers present. For example, an individual with sternal rib data, pubic symphysis, and auricular surface information would be weighted two-thirds transition analysis point estimate and one-third rib score phase midpoint estimate. An individual with only auricular surface and sternal rib information would be weighted one-half transition analysis and one-half sternal rib point estimate.

In order to eliminate the statistical noise associated with single year age at death point estimates in moderate-sized samples, the mortality hazards were combined into five-year brackets and subjected to a smoothing process using STATA's default kernel-weighted local polynomial regression method. This process produces in a much more realistic distribution of the risk of death with less interference from random error associated with sampling methods and the imprecision of skeletal aging methods. However, as the smoothing process eliminates important information from the very front end of the graph related to infant mortality, the initial value on the smoothed graph was replaced with the raw hazard score as initially calculated. The result can be seen as Figure 5.

The resulting estimated mortality profile quite strikingly exhibits all the characteristics one expects from a pre-Industrial human death assemblage. Its slightly left-dipped U-shape resembles mortality curves obtained from medieval European death records as well as developing non-industrial regions of the modern world (Howell 2000; Chamberlain 2006). Moreover, it also manifests details known to characterize historic human populations but entirely unexpected to be so evident in a skeletal sample. The pronounced rise in risk of death, for instance, at around 20 years of age is likely a product of the 'adolescent mortality hump'-a widely recognized phenomenon attributed to risky behavior undertaken by those approaching adulthood, especially young males (Wilson and Daly 1985; Gardner 1993). Its existence at Viminacium is not at all surprising, given 


\section{Estimated Mortality Hazard}

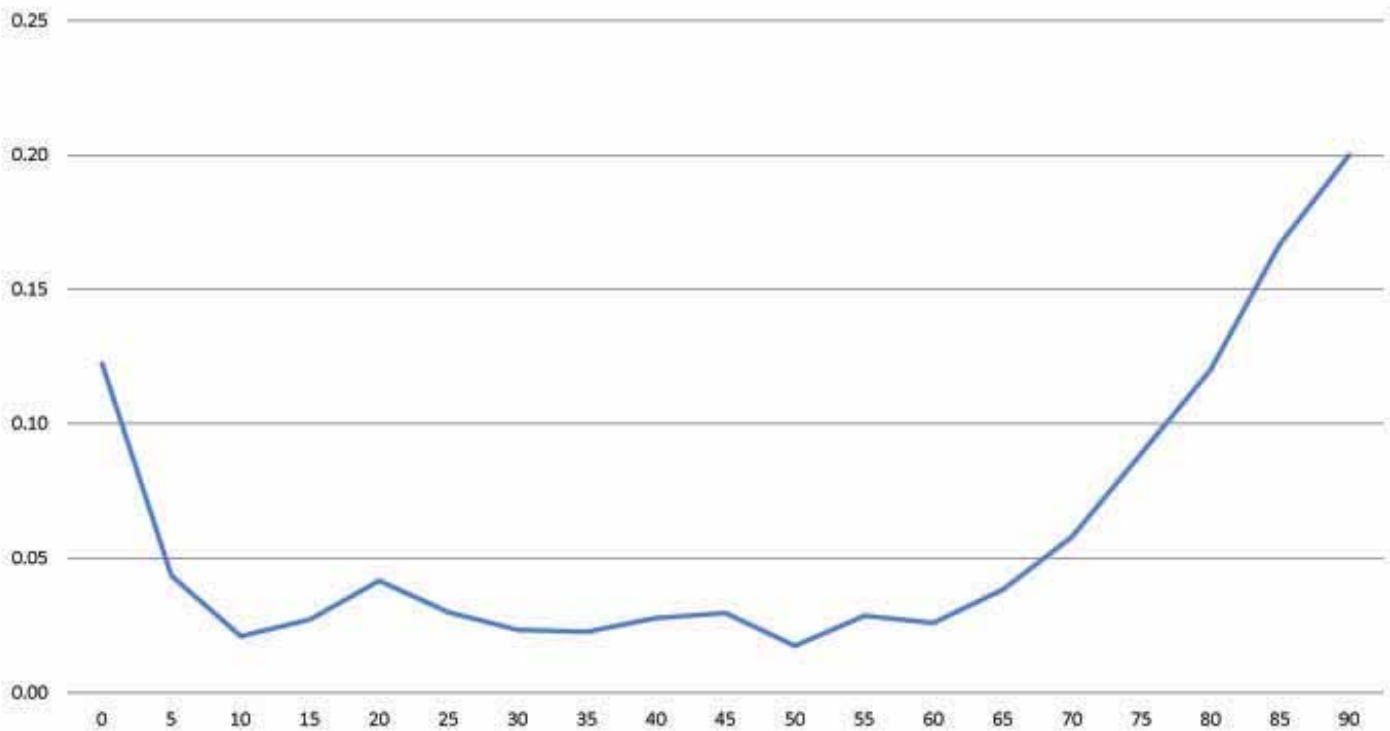

Fig. 5 Estimated Mortality Curve for the Composite Ancient Population of Viminacium. The risk of death is shown vertically along the left edge for each age group presented horizontally along the bottom.

the predominance of males evident in the skeletal assemblage and the martial foundations of the settlement. It is remarkable, however, that such a subtle fluctuation should be apparent in a paleodemographic mortality chart.

An additional factor contributing to this pronounced spike in adolescent/young adult mortality at Viminacium may have been circumstances of intense inward migration to the population. Given the presumably steady influx of new legionary soldiers to the military installation at Viminacium, it is not at all surprising that these young recruits would find their way disproportionally into the graveyards. Even among migrants moving under less stressful and hazardous conditions than military service, it is well-established that recent migrants have a substantially higher risk of death than non-migrants - and that adolescents and young adults are almost universally the ones under the greatest pressure to relocate among human populations (Sharlin 1978; Van der Woude 1982). Risk-bearing young migrants, perhaps both male and female, would almost certainly have contrib- uted to increased adolescent mortality at Viminacium.

Another feature of interest in the Viminacium mortality curve is the set of slight disturbances between about 45 and 65 years of age. These fluctuations from the fairly consistent curve between 20 and 45 years begin with a visible dip at around 50 years of age followed by a small spike at 55 and subsequent dip at around 60 . This minor deviation from an otherwise smooth contour could reflect a glitch in the aging methods, or perhaps represent an artifact of random chance produced by a dwindling number of individuals contributing years lived at this later stage of the life cycle. Yet the curve remains very smooth for the remaining ages beyond 65. Alternatively, this phenomenon could reflect a very real aspect of Roman society documented in the classical literary sources and inscriptions - the retirement and resettlement of legionary veterans. Under the Empire, legionary soldiers were permitted to leave their professional military position after some twenty years of service and receive a pension (praemium) upon doing 


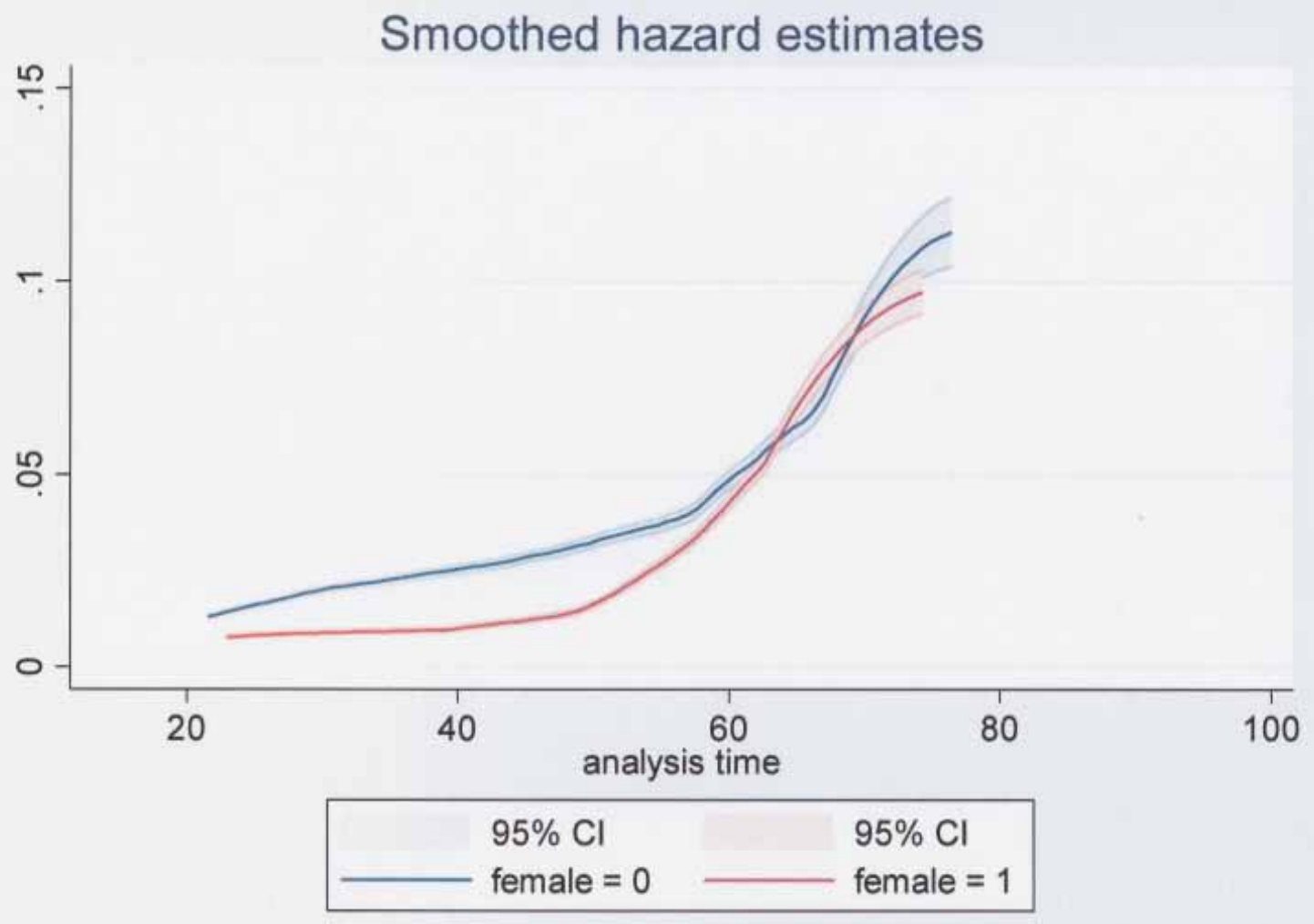

Fig. 6 Statistically Smoothed Risk of Death by Adult Year and Sex at Viminacium $($ Red $=$ Female). $\mathrm{X}$-axis is years of age, $\mathrm{y}$-axis is chance of death per year.

so (Champion 2004; Phang 2008). Veterans were sometimes also given awards of land or resettled in groups as new settlements called colonia. All of these factors could have been an inducement to leave the former legionary station, which would potentially result in fewer persons of retirement age to die and be buried in the graveyards of a military camp like Viminacium. The implication for the present study would be that a substantial number of legionary soldiers were, in fact, surviving to retirement age at Viminacium.

\section{MORTALITY BY SEX}

Using the same combined transition analysis and rib score phase composite age-at-death point estimates, risk of death in the skeletal sample was examined by sex. Because sex cannot be reliably determined from the skeleton before adulthood, sex differences in mortality were only assessed from the end of adolescence onward. Graphs of the results from this aspect of the study therefore necessarily begin only at around age 20 . Risk of death was estimated for the ancient population using STATA's standard non-parametric life table function that employs smoothing and applies a 95\% confidence interval (Cleves et al. 2008:91128). It must be acknowledged in advance that this confidence interval does not take into account the inherent error associated with the skeletal aging process itself. For present purposes, it is necessary to assume that such error is normally distributed and does not introduce any particular directional bias. This is admittedly a large assumption, albeit one that is at present beyond the author's ability to eliminate. The confidence intervals presented in the graphs are therefore somewhat misleadingly narrow. The characteristics of the curves, however, might be assumed to be accurate. 


\section{Kaplan-Meier survival estimates}

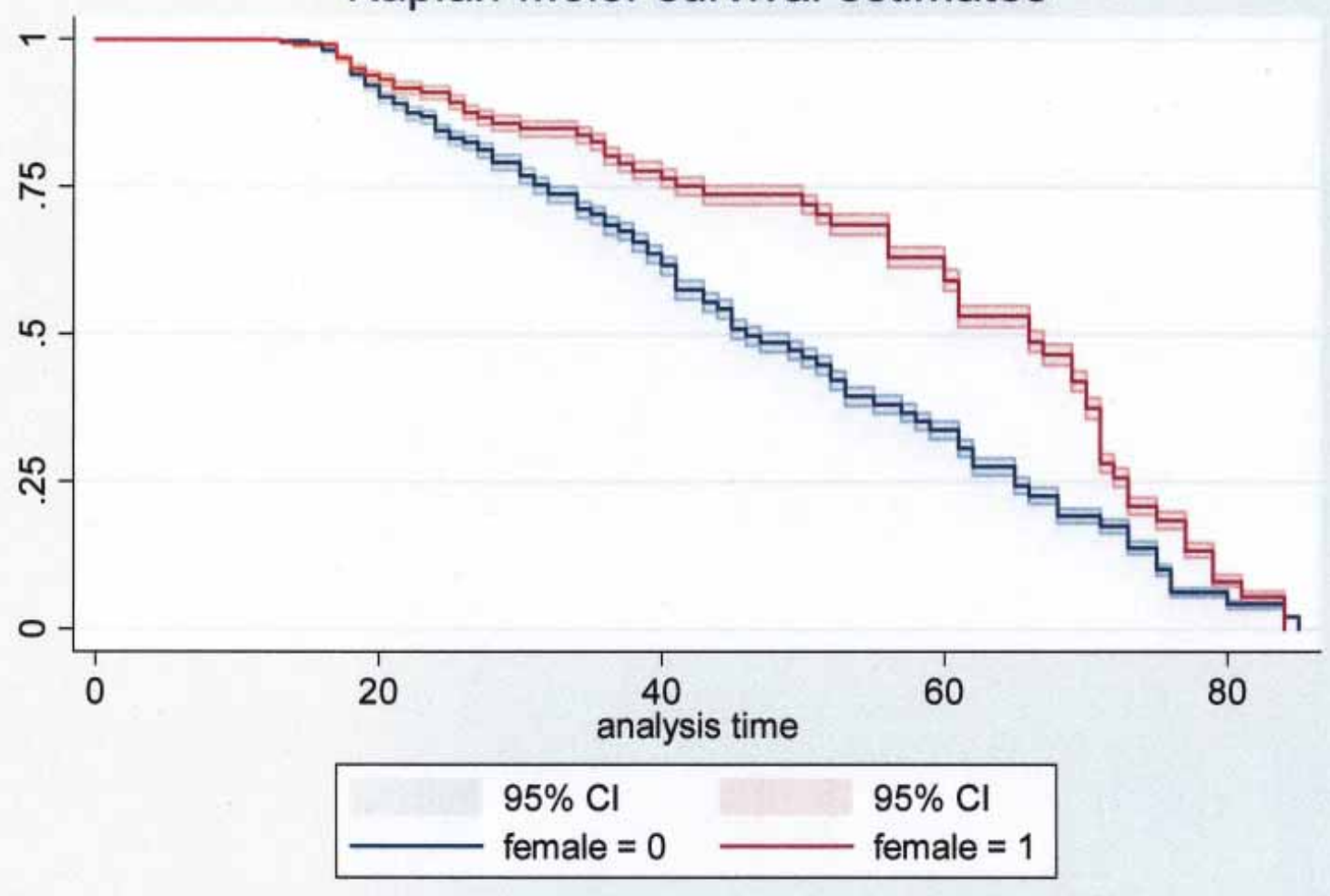

Fig. 7 Differences in Survivorship between Males and Females at Viminacium (Blue = Male). $\mathrm{X}$-axis is years of age, $\mathrm{Y}$-axis is proportion of entering adults remaining in the population.

The results, as one can see from the respective sex-dependant hazard curves (Fig. 6), suggest that adult males consistently experienced a higher risk of death at every age before about their 60th year than did adult females. The crossover at around 65 to 70 may be related to the 'legionary retirement' phenomenon discussed above, and the fact that the fluctuation appears to predominantly be an artifact of the male hazard curve tends to reinforce that interpretation. After about age 60, however, there is no significant difference in mortality hazard, as the curves overlap and do not separate by an amount greater than the estimated confidence interval. The overall effect of this divergence in risk of death between male and female on the population at large can also be appreciated using a survivorship curve, which presents the proportion of an original cohort's expected to survive up to any particular age given the estimated mortal- ity regime. Fig. 7 (below) presents such a graph, constructed using a Kaplan-Meier non-parametric qualitative covariation estimator calculated in STATA (Cleves et al. 2008:93-96). The difference in survivorship between the sexes is quite pronounced, with adult females experiencing a considerable advantage in life expectancy up to about 80 years of age.

In a separate calculation, mean estimated age at death for individual skeletons securely identified as female was $50.75(n=52$, s.d. $=21.8137)$. For those securely identified as male, mean estimated age at death was $40.92(n=88$, s.d. $=$ 19.2026). Using a two-tailed Student's t-test one finds that these two age at death estimates are very significantly different from a statistical perspective $(t=2.7812, \mathrm{df}=138, p=.0062)$. With this information we can estimate that, once they reached adulthood, males lived an average of 9.83 
years less than females, and (assuming no significant directional bias in our skeletal age estimates) we can be $95 \%$ certain that men survived an average of somewhere between 2.84 and 16.82 fewer years than women.

\section{HIDDEN EFFECTS OF SOCIAL STATUS AND TIME}

There are at least two other key variables likely to be obscuring important dimensions of population structure at ancient Viminacium. Firstly, Roman society is well-known to have been characterized by very significant distinctions by social class - ranging from very wealthy patricians all the way down through lowly but freeborn plebs on to slaves whose owners had the very power of life and death over them (Garnsey and Saller 1987; Storey 2000, 2004). Secondly, we can certainly expect that the risk of death from various threats to an individual's well-being changed substantially through time at Viminacium as the settlement evolved from a small military post of perhaps 100 men on the frontier of the empire into the demographically diverse and socially complex capital city of the province of Upper Moesia. It is therefore only prudent to examine how these variables relate to mortality as evidenced by the skeletal remains.

While the assessment of any individual's social status over the course of their life is not easily accomplished through examination of either their skeletal remains or their grave and its accoutrements, many archaeologists over the years have used mortuary treatment as a type of proxy for wealth or political position (Saxe 1970; Binford 1971; Tainter 1975, 1978; Brown 1995; Carr 1995). According to the many variations on the basic proposition, greater energy expenditure in mortuary ritual and/or wealth and diversity in grave inclusions are considered a mark of the higher social rank or socio-economic status of an interred individual while he or she was alive.
Though this equation is not unproblematic and certainly should not be accepted uncritically for all ancient cultures (Ucko 1969; Hodder 1980; Shanks and Tilley 1982), it does seem to hold true in general principle for the classical Mediterranean world. Romans in particular are known to have disposed of the dead using a wide range of methods, with the most highly ranking patricians treated to rather extravagant mausolea and burial crypts while the commoner poor plebians and slaves were left in poorly maintained boneyards (Nock 1932; Toynbee 1971; Reece 1977; Morris 1992). The idea of socio-economic status in Imperial Roman frontier society being reflected to a significant degree in burial treatment was therefore deemed a plausible hypothesis and slated for testing at Viminacium.

To this end, an ordinal scale of evident investment in burial treatment was created for the range of interments found at Viminacium. The mortuary variable found to have the most potential for investigation at the site was grave construction, which takes the form of a broad spectrum of encasement techniques - ranging from no encasement at all to very ornate and elaborate crypts - and with a rather smooth continuum of individually distinguishable gradations in between. The measurement scale was constructed according to several fairly discrete and easily definable categories of increasing energy investment typically found in the site's graveyards. This scale begins with those individuals buried with no encasement at all, scored a ' 1 '. Individuals accompanied by evidence for interment within a wooden coffin by virtue of a series of nails recovered from around the body were scored a ' 2 '. Individuals found within a loose construction of several ceramic tile building slabs, bricks, or roofing tiles were scored with a ' 3 '. And individuals recovered from within a fully constructed brick and mortar crypt or carved sarcophagus were given a ' 4 ' on the mortuary scale. The quantity or quality of funerary goods accompanying an individual was not considered as a part of this analysis. Burial goods were excluded not 


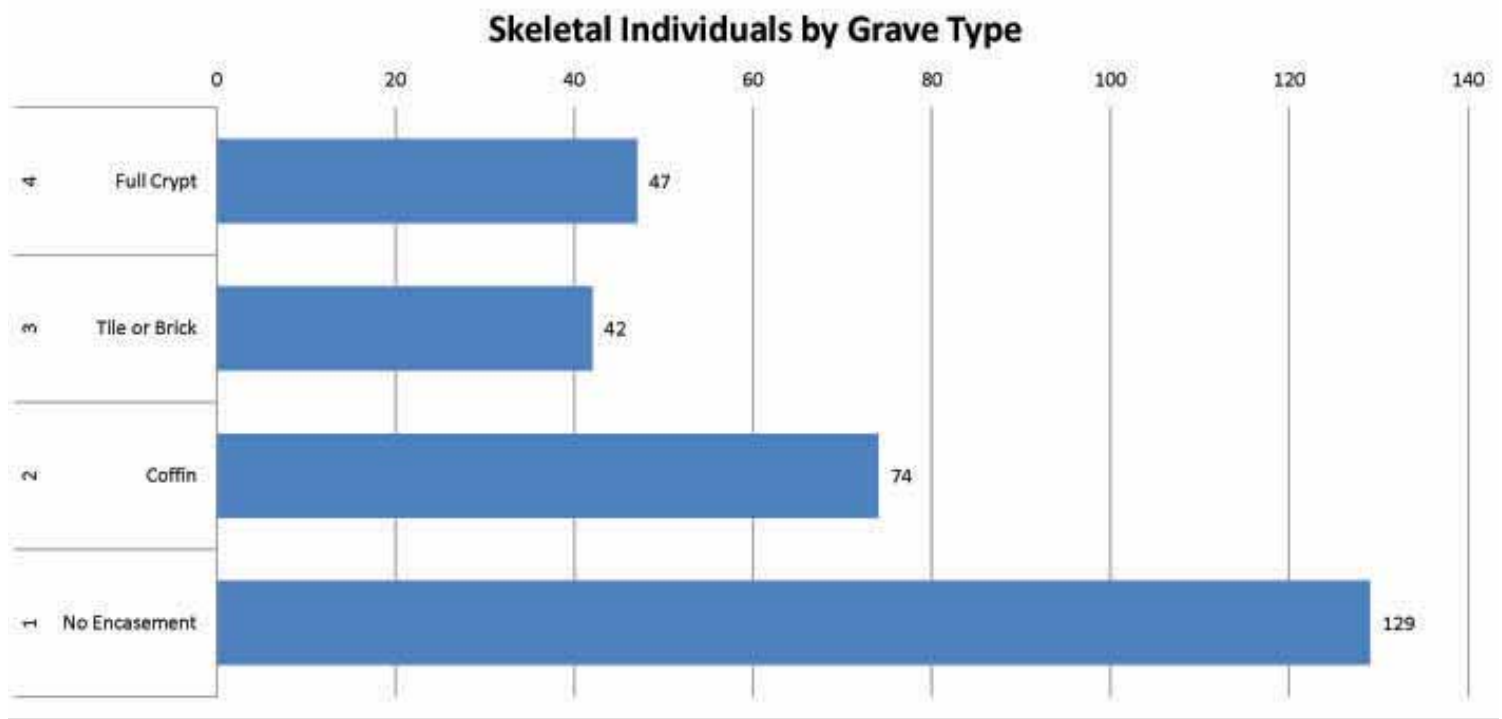

Fig. 8: Individual Frequency of Burial Treatment Types by Presumed Level of Energy Investment.

only because individuals of any rank may acquire one or two items of value during the course of their life, or because such items could have belonged to another individual participating in the interment ceremony and placed in the grave as some sort of symbolic offering, but mostly because so many of the graves in this sample were looted in antiquity and it is precisely these items that are likely to have been taken. Moreover, many such grave goods might have been perishable and are therefore would not have survived for analysis. In addition, many symbolic grave objects - such as metal coins or oil lamps- are likely to have been included for strictly ideological purposes according to alternative religious belief systems, and therefore correlate poorly with the interred person's wealth or political status in life.

The results of this mortuary scale analysis was indeed enlightening (Fig. 8). One can observe that the number of individuals recovered by grave type does in fact roughly present as a 'pyramid' - a system of decreasing frequencies as energy investment increases - theoretically characteristic of social hierarchy. Those interred in constructed tile or brick crypts are far less common than those buried in coffins, which are in turn far less common than individuals buried with no apparent encasement at all. This is exactly what we would expect if the burial treatment of each individual was influenced predominantly by familial wealth or socio-economic status in a hierarchical society in which the greatest number of persons comprised the lowest social classes and the fewest occupied the highest stratum. The single obvious incongruency with the ideal model was an unexpectedly high number of individuals representing the highest level of mortuary investment in the Viminacium sample.

A closer examination of the interment data by sex, however, reveals that the most abundant aspect of the sample, males, is indeed perfectly distributed in decreasing frequency according to presumed energy investment (Table 2). The only abnormality in the hierarchical distribution then can be directly traced to a disproportional number of females buried with the highest level of mortuary investment. Thus, the only aspect of burial treatment at Viminacium that does not appear to adhere to a pyramidal structure of status hierarchy is a strikingly disproportional investment in the mortuary investment afforded to certain women. Mortuary scale 4, reflecting individuals buried in elaborate brick and mortar crypts or sarcophagi, is in fact the only rank at which females outnumber males in the present study. Given what is known 


\begin{tabular}{|c|c|c|c|}
\hline Mortuary Scale & Male & Female & Total \\
\hline 4 & 11 & 18 & 29 \\
\hline 3 & 18 & 8 & 26 \\
\hline 2 & 22 & 10 & 32 \\
\hline 1 & 50 & 27 & 77 \\
\hline Total & 101 & 63 & 164 \\
\hline
\end{tabular}

Table 2: Mortuary Investment by Sex.

\begin{tabular}{|c|c|c|c|c|}
\hline Mortuary Scale & $1^{\text {st }}-2^{\text {nd }}$ Cent & $3^{\text {rd }}$ Cent & $4^{\text {th }}$ Cent & Totals \\
\hline 4 & 2 & 3 & 10 & 15 \\
\hline 3 & 2 & 3 & 13 & 18 \\
\hline 2 & 10 & 10 & 4 & 24 \\
\hline 1 & 13 & 8 & 15 & 36 \\
\hline Total & 27 & 24 & 42 & 93 \\
\hline
\end{tabular}

Table 3: Mortuary Investment by Time Period.

from historical sources about the strongly patriarchal nature of Roman society (Saller 1994; Chrystal 2013), this is a somewhat surprising find. Men in Roman society are generally understood to be the controllers of wealth and manipulators of political power with the very power of life or death over the family (patria potestas), at least under the Republic. But even under the Principate women in many cases were not even permitted by law to manage a family's wealth unless there were no other male relatives available to do so. One plausible explanation for the Viminacium mortuary findings might be a predisposition of high-ranking and wealthy men to invest heavily in funerary ceremony upon the loss of their wives, daughters, and perhaps even mothers given the advanced age of many of these females. What does seem clear is that certain women at Viminacium were being treated inordinately well in death. Given the reduced mortality load women seem to have sustained relative to men described above, one might infer that these women were treated disproportionately well in life as well. Of course, it is necessary to keep in mind that this benefit was not by any means experienced by all women. The most frequent burial treatment encountered for women by this study was plain interment without encasement, just as it was for men. Only some $43 \%$ of women, however, were treated in this manner, compared with about $50 \%$ of men buried with no sign of mortuary encasement.

As the second concern in our examination of population structure, it is also desirable to know how mortuary factors changed through time at ancient Viminacium. If we examine changes in the frequency of various grave types by time period over the course of the city's existence, the results are indeed quite telling. Table 3 shows yet again a generally decreasing number of individuals so interred by increasing level of mortuary investment in the total column by mortuary scale for datable interments - the 'social pyramid' effect. But the most interesting aspects of the data lie in the relative proportions of mortuary scale 2 (coffin burials) versus scale 3 (tile and slab lined graves) and scale 4 (fully constructed crypts) in the latest period of occupation. While coffin graves drop off markedly, both tile and slab-lined graves and crypts soar in popularity.

The increased use of ceramic tile and brick slabs is perhaps unsurprising given the burgeoning ceramic industry at Viminacium, archaeolog- 
ically represented by a large complex of firing kilns at the location of Pećine - not far outside the city walls (Raičković and Redžić 2006). The intensive local manufacture of ceramic building materials would likely have made access to them relatively inexpensive. The great decrease in coffin burials is perhaps indirectly related to this same phenomenon, for the ceramic firing process likely consumed a lot of wood as fuel - thereby contributing to its scarcity as a material for coffins. Larger settlements of the past usually relied first and foremost upon their immediate hinterland for the raw materials they needed for daily life and one of the first resources to be exploited to depletion cross-culturally was wood - for both building and fuel (Christaller 1966; Roberts 1996). As populations grow, people increasingly find it necessary to travel further and further afield to find mature stands of trees to satisfy their community's demand for wood. The transport cost for wood tends to grow exorbitant and other resources are eventually called upon to substitute. Such was probably the case at Viminacium, and by the 4 th Century AD the area around the city may well have been deforested to some distance. By this time, tile slabs and brick had apparently become much more appealing as materials for mortuary construction than was costly wood for coffins.

The consistently increasing proportion of high levels of mortuary investment (Scale 4) to middle (Scales 2 and 3) and low (Scale 1) levels of such through time (Table 3 ) suggests an increasing willingness to invest in funerary treatment, perhaps reflecting the overall increasing prosperity of the settlement. Calculated from Table 3, this ratio would be $1 / 6 / 6.5$ for the 1 st $\& 2$ nd Centuries, 1/4.3/2.7 in the 3rd Century, and 1/1.7/1.5 in the 4th Century. One might expect that the prestige and wealth of a provincial capital would have increasingly appealed to substantial numbers of higher ranking elites as a place to reside in the later periods, and this would explain the increasing proportion of wealthy burials. This fact also tends to discount any movement towards restraint in mortuary be- havior through time as an explanation for the decrease in coffin burial, as if, for instance, the onset of Christianity in the 3rd and 4th Centuries were inducing people to greater humility in choice of burial treatment. If anything, the present study suggests that elaborate graves became more common at Viminacium under Christianity - not less.

\section{CONCLUSIONS}

In sum, several conclusions can be reached based upon the paleodemographic and mortuary data examined here. First and foremost, it has been shown that the skeletal assemblage recovered is both consistent in age-at-death and sex distribution with expectations of a death assemblage from a viable human population. Second, the data have been shown to be roughly in agreement with what has previously been found elsewhere at other cemeteries around Viminacium, suggesting that the results are robust in statistical terms and generally applicable to the population of the ancient city at large. Indications are that the cemeteries located to the east of the castrum do not differ greatly in demographic composition from those situated elsewhere around the perimeter of the city. This tends to discount the notion that graves nearer the castrum have greater association with the military legions than those elsewhere about the ancient city. These findings that the assemblage analyzed here is generally representative of the overall population of Viminacium make some broader socioeconomic and bio-cultural inferences possible. Such inferences are probably best taken as hypotheses for future investigation.

The overall population of Viminacium across the entire period of occupation consisted of about 1.6 males to every female. This aggregate statistic tends to mask changes through time, which is characterized by an extraordinarily high sex ratio of males to females in the earliest periods followed by decreasing values over the subsequent centuries of occupation. Even in the 4th Century, 
however, Viminacium appears to have been predominantly male. A pronounced peak in aggregate (not time-sensitive) late adolescent / young adult mortality observed by this study likely reflects both a continually at-risk age cohort of young males facing military service and a strong influx of young migrants to the city over the centuries. These two explanatory factors are, of course, not mutually exclusive. Future research might examine the relative influence of this phenomenon over time as well as the contribution between males and females. The present study has also suggested that adult males regularly experienced a significantly higher risk of death than did adult females at every age before about their 60th year. The difference in survivorship between the sexes is quite pronounced, with adult females apparently experiencing a considerable advantage in life expectancy once they reached adulthood. This fairly extreme divergence is somewhat paradoxical given the strongly patriarchal nature of Roman society. The implication may be that a patriarchal social organization does not necessarily work entirely against females in all regards.

The creation of an ordinal scale of grave types based strictly upon burial construction has suggested a strongly pyramidal distribution of funerary investment at Viminacium. Given the relatively proportional distribution of demographic and chronological facts across this pyramid, the implication seems to be that social organization at the ancient city was strongly hierarchical, as anticipated, and that burial construction at least roughly correlates social status at the site. The one aspect of burial treatment at Viminacium that did not strongly adhere to a pyramidal distribution was the disproportional investment in mortuary ritual afforded to some females-presumably those of greatest social status - at the highest tier of grave construction. Certain women seem to have been treated inordinately well in death. The mortuary analysis also revealed some interesting trends through time. Coffin burials became increasingly uncommon in the 4th century, and seem to have been mostly replaced by ceramic tile and bricklined grave constructions during this late period. This trend was likely a product of the increasing availability of ceramic and brick construction materials as that industry developed at Viminacium, as well as the increasing scarcity of wood for coffins as the hinterland of the city became increasingly deforested.

To conclude, osteological evidence suggests that the population of ancient Viminacium was always predominantly male - consistent with both the presence of a military installation and scholarly views of pre-Industrial cities as mostly the domain of men. Women, as well as children, were present during all periods examined, however, and were in many cases afforded disproportionally high social status. Men, on the other hand, were at a consistently higher risk of death from at least young adulthood through late middle age. It was evidently the lot of adult males to take on the risks of constructing and maintaining a city on the imperial frontier and defending it against the hazards of the borderlands. The disproportional number of their skeletons in the cemeteries surrounding Viminacium strongly attests to this.

\section{BIBLIOGRAPHY}

\section{Bass, W. M. 2005}

Human Osteology: A Laboratory and Field Manual. Fifth ed. Special Publication No. 2. Missouri Archaeological Society, Columbia, Missouri.

\section{Binford, L. R. 1971}

Mortuary Practices: Their Study and Their Potential. In Approaches to the Social Dimensions of Mortuary Practices, edited by J. Brown: 6-29. Memoir. vol. 25. Society for American Archaeology, Washington, D.C.

Bocquet A., Jean-Pierre, and C. L. Masset 1985 Paleodemography: Resurrection or Ghost? Journal of Human Evolution 14: 107-111. 
Farewell to Paleodemography. Journal of Human

Evolution 11, 1982: 321-333.

\section{Boldsen, J. L. 1997}

Transitional Analysis: A Method for Unbiased Age

Estimation from Skeletal Traits. American Journal of Physical Anthropology (Supplement) 24: 79.

Boldsen, J. L., George R. M., W. Konigsberg L., and Wood J. 2002

Transition Analysis: A New Method for Estimating Age from Skeletons. In Paleodemography: Age Distributions from Skeletal Samples, edited by Robert D. Hoppa, and James W. Vaupel: 73106. Cambridge University Press, Cambridge UK.

\section{Brooks, S. T. and Suchey J. M 1990}

Skeletal Age Determination based on the Os Pubis: A Comparison of the Acsádi-Nemeskéri and Suchey-Brooks Methods. Human Evolution (5):227-238.

\section{Brown, J. 1995}

On Mortuary Analysis-With Special Reference to the Saxe-Binford Research Program. In Regional Approaches to Mortuary Analysis, edited by Lane Anderson Beck. Plenium Press, New York.

\section{Buckberry, J. L. and Chamberlain A. 2002}

Age Estimation from the Auricular Surface of the Illium: A Revised Method. American Journal of Physical Anthropology 119: 231-39.

Buikstra, J. E., and Ubelaker D. 1994 Standards for Data Collection from Human Skeletal Remains: Proceedings of a Seminar at The Field Museum of Natural History. Arkansas Archaeological Survey Research Series 44. Arkansas Archaeological Survey, Fayetteville.

Buikstra, J. E., W. Konigsberg L., and Bullington J. 1985

Paleodemography: Critiques and Controversies. American Anthropologist (87): 316-333.

\section{Carr, Ch. 1995}

Mortuary Practices: Their Social, Phiolosophical-Religious, Circumstantial, and Physical Determinants. Journal of Archaological Method and Theory 2: 105-200.

\section{Chamberlain, A. T. 2006}

Demography in Archaeology. Cambridge Manuals in Archaeology. Cambridge University Press, Cambridge UK.

\section{Champion, C. B. 2004}

Roman Imperialism: Readings and Sources. Blackwell Publishing, Malden, MA.

\section{Christaller, W. 1966}

Central Places in Southern Germany. Prentice-Hall, Englewood Cliffs NJ.

\section{Chrystal, P. 2013}

Women in Ancient Rome. Amberley, Glouchestershire UK.

Cleves, M. A., William W. G., G. Gutierrez R., and Marchenko U. Y. 2008

An Introduction to Survival Analysis Using Stata. Second ed. Stata Press, College Station TX.

Cohen, M. N. 1989

Health and the Rise of Civilization. Yale University Press, New Haven CT.

\section{Fenner, F. 1970}

The Effects of Changing Social Organization on the Infectious Diseases of Man. In The Impact of Civilization on the Biology of Man, edited by S.V. Boyden: 48-76. Australian National University Press, Canberra AUS.

\section{William G. 1993}

A Life-Span Rational-Choice View of Risk Taking. In Adolescent Risk Taking, edited by Nancy J. Bell and Robert W. Bell: 66-83. Sage Publications, Newbury Park, California. 


\section{Garnsey, P. and Saller R. 1987}

The Roman Empire: Economy, Society and Culture. University of California, Berkeley CA.

\section{Hillson, S. 2005}

Teeth. 2nd ed. Cambridge University Press, New York.

\section{Hodder, I. 1980}

Social Structure and Cemeteries: A Critical Appraisal. In Anglo-Saxon Cemeteries, edited by P. Rahtz, T. Dickinson, and L. Watson, pp. 161-170. British Archaeological Reports. vol. 82, Oxford.

\section{Howell, N. 2000}

Demography of the Dobe !Kung. Second ed. Aldine de Gruyter, New York.

Iscan, M. Y., and Loth S. 1986

Estimation of Age and Determination of Sex from the Sternal Rib. In Forensic Osteology: Advances in the Identification of Human Remains, edited by Kathleen J. Reichs: 68-89. Charles C. Thomas, Springfield IL.

\section{Iscan, M.Y., S. R. L. and R. K. Wright 1985}

Age estimation from the rib by phase analysis: White females. Journal of Forensic Sciences 30: 853-63.

Age estimation from the ribs by phase analysis: White males. Journal of Forensic Sciences 64 1984: 53-57.

\section{Jovanovic, B. 1984}

Les sépultures de la nécropole céltique de Pecine pres de Kostolac. Etudes Celtiques 21: 64-93.

\section{Korać, M. and Golubović S. 2009}

Viminacum Više Grobalja, Volume 2: Cremations $281-530$ and Inhumations 268-550. Arheološki institut Beograd, Belgrade, Serbia.

\section{Krogman, W. M. 1962}

The Human Skeleton in Forensic Medicine. Charles C. Thomas, Springfield IL.

Lovejoy, C. O. Richard S. M., Thomas R. P. and Robert P. M. 1985

Chronological Metamorphosis of the Auricular Surface of the Illium: A New Method for the Determination of Adult Skeletal Age at Death. American Journal of Physical Anthropology 68: 15-28.

Mikic, Ž. 2006

Trepanacija lobanja na antickom Viminacijumu - antropoloske informacije [Trepanation of the Skull at Antique Viminacium - Anthropological Information]. Arheologia i Prirodne Nauke [Archaeology and Science] 1: 9-20.

O trepanaciji lobanja kao antropologskom fenomenu [On Trepanation of the Cranium as an Anthropological Phenomenon]. Zbornik Narodnog Museja [Anthology of the National Museum] 16(1) 1996: 323-9.

Antropoloski osvrt na vestacki deformicane lobanje iz Perioda Velike Seobe Naroda [Anthropological Report on Artificial Cranial Deformation from the Period of the Great Migrations]. Convention of the National Museum [Belgrade] 15(1) 1994: 133-8.

\section{Mirković, M. 1968}

Rimski gradovi na Dunavu u Gornjoj Meziji. Arheolosko Drustvo Jugoslavije, Beograd.

Mócsy, A. 1974

Pannonia and Upper Moesia: A History of the Middle Danube Provinces of the Roman Empire. Routledge, Boston.

\section{Morris, I. 1992}

Death-ritual and Social Structure in Classical Antiquity. Cambridge University Press, Cambridge. 


\section{Nock, A. D. 1932}

Cremation and Burial in the Roman Empire. Harvard Theological Review 25(4): 321-359.

\section{Phang, S. E. 2008}

Roman Military Service: Ideologies of Discipline in the Late Republic and Early Principate Cambridge University Press, Cambridge.

\section{Phenice, T.W. 1969}

A newly developed visual method of sexing in the Os pubis. American Journal of Physical Anthropology (30): 297-301.

\section{Radojčić, N. and Vasić M. 2003}

Archaeological Journey in the Iron Gates. National Museum Belgrade, Belgrade.

\section{Raičković, A. and Redžić S. 2006}

Keramički i Opekarske Peći Viminacijuma: Lokacije "Pećine" i "Livade Kod Ćuprije". Arheologija i Prirodne Nauke 1: 81-106.

Reece, R. (ed.) 1977

Burial in the Roman World. Council of British Archaeology, London.

Roberts, B. K. 1996

Landscapes of Settlement: Prehistory to the Present. Routledge, New York.

Saller, R. P. 1994

Patriarchy, Property and Death in the Roman Family Cambridge University Press, Cambridge.

\section{Sattenspiel, L. and Harpending H. 1983}

Stable Populations and Skeletal Age. American Antiquity 48(3): 489-98.

Saxe, A. 1970

Social Dimensions of Mortuary Practices. Unpublished Ph.D. dissertation, Department of Anthropology, University of Michigan, Ann Arbor.

\section{Schutkowski, H. 1993}

Sex Determination of Infant and Juvenile Skeletons: I. Morphognostic Features. American Journal of Physical Anthropology 90: 199-205.

\section{Shanks, M. and Tilley Ch.1982}

Ideology, Symbolic Power and Ritual Communication: A Reinterpretation of Neolithic Mortuary Practices. In Symbolic and Structural Archaeology, edited by Ian Hodder. Cambridge University Press, Cambridge.

\section{Sharlin, A. 1978}

Natural Decrease in Early Modern Cities: A Reconsideration. Past and Present 79: 126-38.

\section{Spasić-Djurić, D. 2002}

Viminacium: The Capital of the Roman Province of Upper Moesia. National Museum Pozarevac, Pozarevac.

\section{Speal, C. S. 2008}

Evaluating Intercostal Variability in Sternal Rib Ends for Purposes of Skeletal Aging. Arheologia $i$ Prirodne Nauke 3: 31-36.

\section{Storey, G. R. (ed.) 2006}

Urbanism in the Preindustrial World: Cross-Cultural Approaches. University of Alabama Press, Tuscaloosa AL.

Roman Economies: A Paradigm of Their Own. In Archaeological Perspectives on Political Economies, edited by Gary M. Feinman and Linda M. Nicholas, 2004: 105-128. University of Utah Press, Salt Lake City.

Cui Bono? An Economic Cost-Benefit Analysis of Statuses in the Roman Empire. In Hierarchies in Action: Cui Bono?, edited by Michael W. Diehl. Occasional Paper No. 27, 2000, Southern Illinois University, Carbondale. 


\section{Tainter, J. A. 1978}

Mortuary Practices and the Study of Prehistoric Social Systems. In Advances in Archaeological Method and Theory, edited by Michael B. Schiffer, pp. 105-41. Academic Press, New York.

Social Inference and Mortuary Practices: An Experiment in Numerical Classification. World Archaeology (7) 1975: 1-15.

\section{Todd, T. W. 1920}

Age Changes in the Pubic Bone: I. The White Male Pubis. American Journal of Physical Anthropology 3: 467-70.

\section{Toynbee, J. M. C. 1971}

Death and Burial in the Roman World. Cornell University Press, Ithaca NY.

\section{Ubelaker, D. H. 1989}

Human Skeletal Remains: Excavation, Analysis, Interpretation. 2nd ed. Taraxcum, Washington DC.

\section{Ucko, P. J. 1969}

Ethnography and the Archaeological Interpretation of Funerary Remains. World Archaeology 1: 262-90.

\section{Van der Woude, A. M. 1982}

Population Developments in the Northern Netherlands (1500-1800) and the Validity of the "Urban Graveyard" Effect. Annales de demographie historique 1982: 55-75.

\section{Wilson, M. and Martin D. 1985}

Competitiveness, Risk Taking, and Violence: The Young Male Syndrome. Ethology and Sociobiology 6: 59-73.

\section{Workshop of European Archaeologists 1980}

Recommendations for Age and Sex Diagnoses of Skeletons. Journal of Human Evolution 9: 517549 .

\section{Wrigley, E.A. 1967}

A Simple Model of London's Importance in Changing English Society and Economy 16501750. Past and Present 37: 44-70.

Yoder, Cassady J., Douglas H. Ubelaker, and J. F. Powell 2001

Examination of Variation in Sternal Rib End Morphology Relevant to Age Assessment. Journal of Forensic Sciences 46: 223-227.

\section{Zotović, Lj., and Jordović Č.1990}

Viminacium: Necropole "Više Grobalja". Arheološki Institut, Beograd. 
REZIME

PALEODEMOGRAFIJA /

PROUČAVANJE GROBOVA

IZ ISTOČNIH NEKROPOLA

VIMINACIJUMA

KLJUČNE REČI: PALEODEMOGRAFIJA, ANTIČKI GRADOVI, VIMINACIUM, POL I ROD U RIMSKOM PROVINCIJISKOM DRUŠTVU.

Članak predstavlja pregled paleodemografskih podataka dobijenih nakon šest sezona terenskih istraživanja sprovedenih u Viminacijumu - provincijskom gradu na dunavskoj granici Rimskog carstva. Analizirani su skeletni ostaci iz 254 gro- bova sa 297 individua koji potiču iz četiri nekropole koje se nalaze na istočnom obodu antičkog grada. Rezultati ukazuju da se ispitivan skeletni uzorak može smatrati reprezentativnim pokazateljem smrtnosti antičke populacije u celini. Glavni demografski podaci dobijeni tokom istraživanja pokazuju znatno veći udeo muškaraca u populaciji tokom čitavog trajanja antičkog grada, dok s druge strane značajno duži životni vek među ženama. Analiza materijala je takođe pokazala još neke zanimljive rezultate, kao što je smanjenje upotrebe drvenih sanduka u kasnijem periodu rimske dominacije ili nejednak tretman u sahranjivanju ženskih individua. 